\title{
Santia katoi sp. nov., a New Isopod Crustacean from Shirahama, Japan (Asellota: Santiidae)
}

\section{$\operatorname{AUTHOR}(\mathrm{S})$ :}

Shimomura, Michitaka; Mawatari, Shunsuke F.

\section{CITATION:}

Shimomura, Michitaka ...[et al]. Santia katoi sp. nov., a New Isopod Crustacean from Shirahama, Japan (Asellota: Santiidae). PUBLICATIONS OF THE SETO MARINE BIOLOGICAL LABORATORY 2000, 39(1): 29-34

ISSUE DATE:

2000-12-25

URL:

http://hdl.handle.net/2433/176292

RIGHT: 


\title{
Santia katoi sp. nov., a New Isopod Crustacean from Shirahama, Japan (Asellota: Santiidae)
}

\author{
Michitaka SHIMOMURA and SHUNSUKe F. MAWATARI
}

Division of Biological Sciences, Graduate School of Science, Hokkaido University, Sapporo 060-0810, Japan

\begin{abstract}
Santia katoi sp. n. is described from Shirahama, Wakayama Prefecture, as the first record of the family Santiidae (Isopoda: Asellota) from Japan. The new species differs from its congeners in having a convex frontal margin on the head, coxal plates 5-7 each with two setae, and the male pleopod 1 with the distolateral projections on apex.
\end{abstract}

Key words: Santia katoi sp. nov., Santiidae, Shirahama, Asellota, Isopoda

\section{Introduction}

Santiidae are a small family in the suborder Asellota, of four genera and 18 species (Wolff, 1989), all of which are marine benthic dwellers known mostly from shallow waters. Santia Sivertsen and Holthuis, 1980, the largest genus in the family, includes 13 species (Wolff, 1989), of which most are distributed in the Southern Hemisphere except for Santia hirusta (Menzies, 1951) from California and S. milleri (Menzies and Glynn, 1968) from Puerto Rico.

Our recent investigations yielded an undescribed species of Santia from the subtidal zone of Shirahama coast, Wakayama Prefecture, the first record of the family from Japan and the third record of the genus from the Northern Hemisphere.

\section{Material and Methods}

Most specimens were obtained by hand sorting from the surface of dead corals, which were collected by snorkeling in shallow water. Sediment samples obtained by a Smith-McIntyre grab were washed in a plastic bucket, and animals were extracted by decanting the suspension through a sieve with a pore size of $0.1 \mathrm{~mm}$. All the specimens obtained were fixed with $5 \%$ neutralized formalin solution diluted with seawater and preserved in $70 \%$ ethanol. Each individual was dissected and prepared for observation by a light microscope equipped with Nomarski differential interference contrast device (Shimomura and Mawatari, 1999). Total length as indicated below under the "Material examined" was measured from tip of head to end of pleotelson.

The type series are deposited in the Zoological Museum, Division of Biological Sciences, Graduate School of Science, Hokkaido University (ZIHU).

\section{Santia katoi sp. nov.}

(Figs. 1-2)

Material examined

Shirahama, Wakayama Prefecture, Japan. Holotype: male, 0.9 mm (ZIHU-01301), 
subtidal zone in front of the Seto Marine Biological Laboratory, snorkeling, $4 \mathrm{~m}$, dead corals, 14 May 1998, T. Kato. Paratypes: 2 ovigerous females, $1.1 \mathrm{~mm}$ (ZIHU-01302), $1.1 \mathrm{~mm}$ (ZIHU-01303), data same as holotype; 2 females, $1.4 \mathrm{~mm}$ (ZIHU-01304), $1.5 \mathrm{~mm}$ (ZIHU-01305), data same as holotype; 1 female, $0.9 \mathrm{~mm}$ (ZIHU-01306), off Shiso-Jima Isl., Smith-McIntyre grab, $10 \mathrm{~m}$, sand and mud, 17 Nov. 1997 M. Shimomura. Additional specimens: 8 females, 1.0-1.4 mm (ZIHU-01307-14), data same as holotype.

\section{Description}

Body (Fig. 1A) 2.3 times as long as maximum width. Head with 8-9 dorsal setae, twice as broad as long, wider than pereonite 1; frontal margin convex, with 4 setae; upper lip surpassing head anteriorly; posterior margin nearly straight. Eyes each with 7-10 ommatidia; eyestalks short, on posterior half of head, with 1 anterolateral, 1-2 dorsolateral, 1 posterolateral and 1 ventrolateral setae. Pereonites 1-4 with 5-15 dorsolateral setae; pereonites 5-7 with a pair of mid-dorsal and 2-4 dorsolateral setae. All pereonites with rounded corners; pereonite 1 narrower than pereonites 2-4; pereonites 2-4 subequal in width; pereonites 5 to 7 decreasing in width. Pereonite 1 shorter than pereonites 2-4; pereonites 2-4 subequal in length; pereonite 5 shortest; pereonites 6 and 7 subequal in length. Coxal plates dorsally visible on pereonites 5-7; coxal plates of pereonites 2-4 without setae; coxal plates of pereonites 5-7 each with two setae. Pleonite sunken into pereonite 7, without setae. Pleotelson (Figs. $1 \mathrm{~A}, \mathrm{~B}$ ) barrel-shaped, with short rounded projection apically, with 11 dorsal setae, a pair of midlateral and apical setae, 1-2 pairs of stout spines and 3-4 setae ventrally. Uropod (Fig. 1 C) stout, consisting of peduncle, exopod and endopod, directed posteriorly, longer than pleotelson. Peduncle wide posteriorly, half as long as exopod, with 0-1 dorsal seta and 1 mesial, 0-1 distolateral sensory spines. Exopod and endopod cylindrical, longer than broad. Exopod 1.5 times as long as endopod, with 3 sensory spines and $0-1$ seta apically, 2-10 lateral, 4-8 mesial sensory spines. Endopod slightly narrower than exopod, with 2-3 sensory spines and 3 filoplume-like setae apically, 2-4 lateral, 3-5 mesial sensory spines.

Antenna 1 (Fig. 1 D) peduncle article 1 slightly shorter than article 2, with 1 distal filoplume-like seta; article 2 narrower than article 1, with 2 setae and 2 filoplume-like setae distally; article 3 narrower and shorter than 2; flagellum article 1 as long as peduncle article 3 ; article 2 three times as long as article 1, apically with 1 aesthetasc and 1 long, 1 short, 1 filoplume-like setae.

Antenna 2 (Fig. $1 \mathrm{E}$ ) peduncle of 5 articles: article 1 widest, without setae; article 2 longer than article 1 , with 1 lateral convex protrusion with single seta; article 3 shortest, with 1 distal seta; article 4 with 2 setae and 1 filoplume-like seta distally and 1 filoplume-like seta laterally; article 5 longest, with 15 setae and 2 distal filoplume-like setae. Flagellum of 9 articles each with 1-4 distal setae, slightly longer than peduncular articles 1 to 5 combined.

Left mandible (Fig. $1 \mathrm{~F}$ ) palp slender; article 1 shorter than article 2; article 2 longest, with 1 seta; article 3 minute, with 1 apical seta. Incisor with 4 cusps; lacinia mobilis with 3 teeth; spine row with 4 spines; molar process with single seta.

Right mandible (Fig. $1 \mathrm{G}$ ) lacking lacinia mobilis. Palp slender, article 1 shorter than article 2; article 2 longest, with 2 setae; article 3 minute, with 1 apical seta. Incisor with 3 cusps; spine row with 5 spines; molar process with 2 setae.

Maxilla 1 (Fig. $1 \mathrm{H}$ ) inner lobe with 10 apical setae; outer lobe with 4 apical setae.

Maxilla 2 (Fig. $1 \mathrm{I}$ ) inner lobe bearing 7 setae apically, 1 long seta distomesially, 9 setae mesially; outer 2 lobes with 2 simple and 1 pectinate setae apically. 


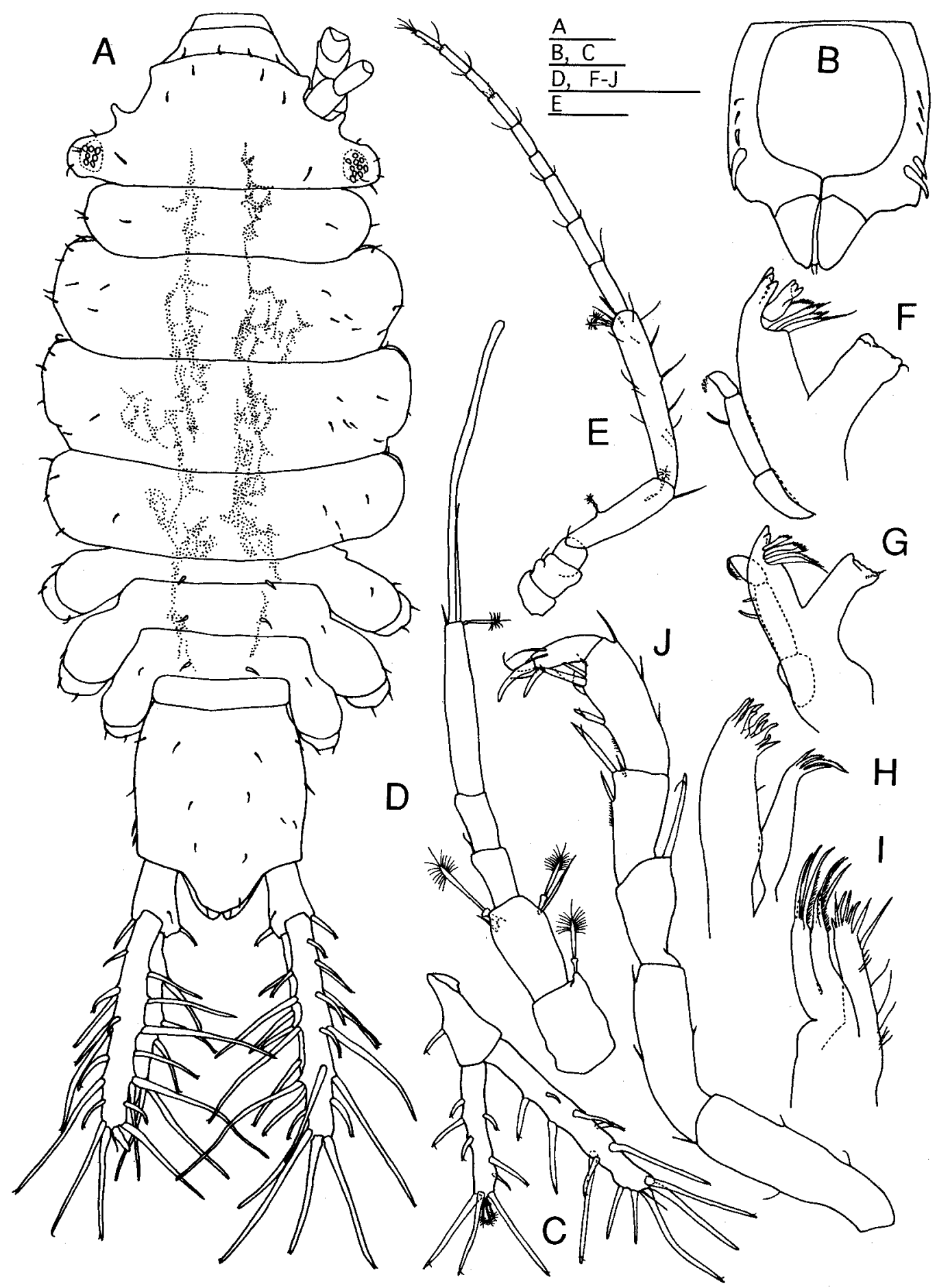

Fig. 1. Santia katoi sp. nov. A, B, F, paratype, ZIHU-01304; C, G, J, holotype; D, E, H, I, paratype, ZIHU-01302: A, female; B, pleotelson; C, uropod; D, antenna 1; E, antenna 2; F, left mandible; G, right mandible; $\mathrm{H}$, maxilla $1 ; \mathrm{I}$, maxilla $2 ; \mathrm{J}$, pereopod 1 . Scales $=0.1 \mathrm{~mm}$. 


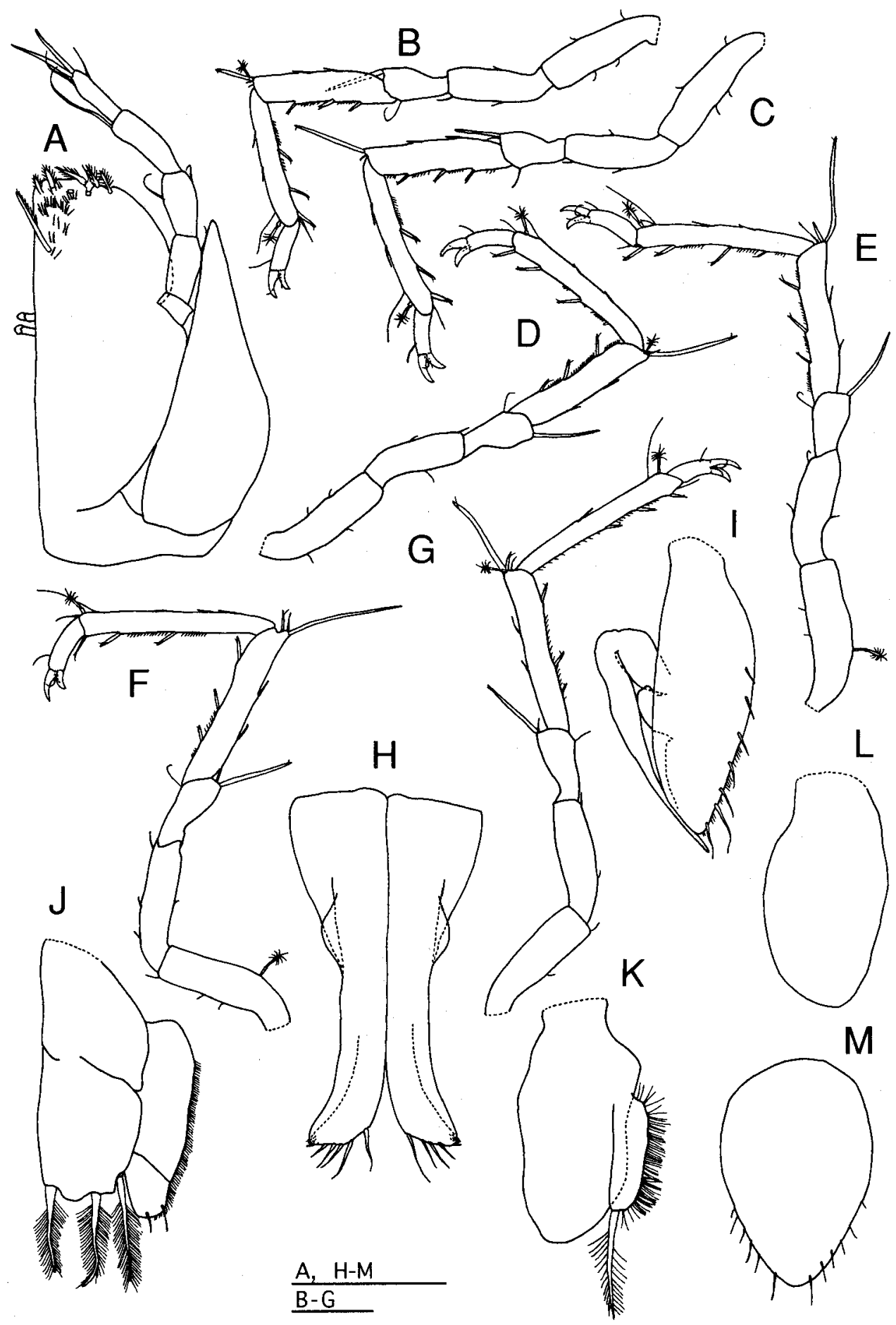

Fig. 2. Santia katoi sp. nov. A, J-M, paratype, ZIHU-01302; B-G, H, I, holotype: A, maxilliped; B-G, pereopods 2-7; $\mathrm{H}$, pleopod 1; I, pleopod 2; J-L, pleopods 3-5; $\mathrm{M}$, operculum. Scales $=0.1 \mathrm{~mm}$. 
Maxilliped (Fig. 2 A) palp of 5 articles, slender; article 1 shortest; articles 2-4 subequal in length and width; article 5 narrowest, with 4 apical setae; endite semicircular, bearing 4 pectinate setae and 1 fan-shaped seta distally and 2 coupling hooks mesially; epipod lanceolate, narrower than endite, reaching third palp article, with pointed apex.

Pereopod 1 (Fig. $1 \mathrm{~J}$ ) shorter than pereopods 2-7: basis longest, with 2 ventral, 2 dorsal setae; ischium shorter than basis, with 2 ventral, 1 dorsal setae; merus trapezoidal, with 1 long sensory robust seta distally; carpus as long as merus, with 2 sensory robust setae and 1 seta distally, a row of tiny setae ventrally; propodus longer than carpus, with 3 sensory robust setae, a row of tiny setae and further setae ventrally and 3 setae dorsally; dactylus shorter than propodus, narrowest, with 4 distal setae, 1 curved unguis and slender supplementary claw.

Pereopods 2-6 (Figs. 2 B-G) increasing in length posteriorly; pereopod 7 shorter than 6: basis dorsally with 0-2 setae and 0-1 filoplume-like seta, 1-2 ventral setae; ischium shorter than basis, with 1-4 setae; merus half as long as ischium, dorsodistally with 1 long sensory robust seta and $0-1$ short seta, 1 ventrodistal seta; carpus as long as ischium, dorsodistally with 1 long, 0-1 short sensory robust, 0-1 filoplume-like and 1-2 short setae, dorsally with 2 short setae, and ventrally with 3 sensory robust setae and a row of tiny setae; propodus longest, dorsodistally with 1 filoplume-like seta and 1-2 simple setae, 2 dorsal setae, 3 sensory robust setae and a row of tiny setae and 1-2 short setae ventrally; dactylus shortest, with 1 dorsal seta, 2 distal setae, 1 curved unguis and robust supplementary claw.

Male pleopod 1 (Fig. $2 \mathrm{H}$ ) distally separate, with distolateral projections on apex, each with 4-5 apical setae; pleopod 2 (Fig. 2 I) protopod narrow, 3 times as wide as long, laterally with 7 setae and a row of tiny setae; endopod surpassing protopod with slender second article; exopod stout.

Pleopod 3 (Fig. $2 \mathrm{~J}$ ) endopod with 3 stout plumose setae apically; exopod of 2 articles narrower than endopod, lateral margin setose; article 2 with 2 short apical setae. Pleopod 4 (Fig. $2 \mathrm{~K}$ ) exopod with 1 long plumose seta apically, lateral margin setose; endopod broader than endopod. Pleopod 5 (Fig. $2 \mathrm{~L}$ ) ovate, uniramous, twice as long as broad.

Female operculum (Fig. $2 \mathrm{M}$ ) ovate, 1.5 times as long as broad, with 6 pairs of setae laterally.

\section{Remarks}

The following features displayed by the new species indicate that it belongs to Santia: antenna in anterior indentations laterally on the head, directed process in front of the eyestalks, pleotelson apically with short rounded projection, 3-articulated mandibular palp, male pleopod 1 without lateral horns, female operculum longer than broad, uropods with stout protopod, cylindrical endopod and exopod.

The stout uropod with the exopod longer than the endopod links the new species to Santia mawsoni (Hale, 1937) from the Antarctic (type locality) and Chile (Menzies, 1962) and $S$. milleri (Menzies and Glynn, 1968) from Caribbean Sea (type locality). Santia katoi is distinguished from $S$. mawsoni by the following features (those of $S$. mawsoni in parentheses): the convex anterior margin of head (concave), the head wider than pereonite 1 (narrower), the pleotelson without lateral spines (with 1-2 pairs of lateral spines) and the distolateral projected apex of pleopod 1 in male (without distolateral projections). Santia katoi differs from $S$. milleri in having the following features (those of $S$. milleri in parentheses): the coxal plates 5-7 each with two setae (1 stout spine), the nearly straight posterior margin of head (convex) and the pleotelson with lateral and dorsal setae (without 
lateral and dorsal setae).

All the specimens are red due to a large number of tiny red algae growing on the integument of body and appendages except for eyes, the flagellum of antennae 1 and 2 , dactylus, propodus, carpus and merus of all pereopods and pleopods 3-4. Each alga is unicellular and spherical of about $20 \mu \mathrm{m}$ in diameter.

\section{Etymology:}

This species is named after Mr. Tetsuya Kato, who collected most of the type series of this species.

\section{Acknowledgments}

Our thanks go to Dr. Gary C. B. Poore of the Museum of Victoria, for critically reading an earlier draft of the manuscript. We are grateful to Mr. Tetsuya Kato, Hokkaido University for collecting specimens. Thanks are due to Dr. Yoshikazu Takashima, Hokkaido University, for his help in the field. Thanks are also due to the staffs of the Seto Marine Biological Laboratory, Kyoto University for providing facilities.

\section{References}

Amar, R. and Roman, M.-L. 1973. Invértebrés marins des XIIème et XVème Expéditions Antarctiques Françaises en Terre Adélie 14. Tanaidacés et Isopodes. Tethys, 5, 562-599.

Hale, H. M. 1937. Isopoda and Tanaidacea. Scientific reports (Ser. C), Australian Antarctic Expedition $1911-14,2,1-45$.

Menzies, R. J. 1951. New marine isopods, chiefly from northern California, with notes on related forms. Proceedings of the United States National Museum, 101, 105-156.

Menzies, R. J. 1962. Reports of the Lund University Chile Expedition 1948-49, 42. The zoogeography, ecology and systematics of the Chilean marine isopods. Acta Universitets Lundensis, 2, 1-162.

Menzies, R. J. and Glynn, R. W. 1968. Studies on the Fauna of Curaçao and other Caribbean Islands 27. The common marine isopod Crustacea of Puerto Rico. Uitgaven van de Natuurwetenschappelijke Studiekring voor Suriname en de Nederlandse Antillen, 51, 1-133.

Shimomura, M. and Mawatari, S. F. 1999. Paramunna rhipis, a new species of asellote isopod (Paramunnidae) from Japan. Crustacean Research, 28, 153-159.

Wolff, T. 1989. The genera of Santiidae Kussakin, 1988, with the description of a new genus and species (Crustacea, Isopoda, Asellota). Steenstrupia, 15, 177-191. 